\title{
MUTU TEMPE VARIASI KACANG TANAH DAN KEDELAI
}

\author{
Arif Murtaqi Akhmad Mutsyahidan ${ }^{1)}$, Desi Arisanti' ${ }^{2)}$, Pemriliani Suleman ${ }^{3)}$ \\ 1. Dosen Program Studi Teknologi Hasil Pertanian, Politeknik Gorontalo \\ 2. Dosen Program Studi Teknologi Hasil Pertanian, Politeknik Gorontalo \\ 3. Mahasiswa Program Studi Teknologi Hasil Pertanian, Politeknik Gorontalo \\ Email: arifmams@poligon.ac.id ${ }^{1)}$
}

\begin{abstract}
ABSTRAK
Tempe merupakan makanan tradisional yang telah lama dikenal di Indonesia. Penelitian tentang mutu tempe variasi kacang tanah dan kedelai ini bertujuan untuk melihat variasi pembuatan tempe menggunakan kacang tanah dan kedelai. Pengujian tempe variasi kacang tanah dan kedelai dalam penelitian ini yaitu mengunakan uji organoleptik serta melakukan analisis kimia seperti kadar air, kadar abu, dan kadar lemak.

Hasi uji organoleptik terhadap rasa menujukan bahwa tingkat kesukaan panelis terhadap perlakuan T3 lebih tinggi dibanding T1 dan T2. Hasil uji organoleptik terhadap aroma menunjukan bahwa perlakuan T2 lebih tinggi dibanding T1 dan T3. Hasil uji organoleptik terhadap tekstur menunjukkan bahwa T1 lebih tinggi disbanding T2 dan T3. Nilai rata-rata kadar air yaitu T2 memiliki nilai kadar air 56,47\%, T1 memiliki nilai kadar air 55,17\% dan T3 memiliki nilai 50,45\%. Nilai rata-rata kadar abu perlakuan T1 0,59\%, T2 0,90\%, dan T3 0,67\%. Nilai kadar lemak tertinggi pada perlakuan $\mathrm{T} 3$ yaitu $4,93 \%$ sedangkan rata-rata kadar lemak yang terendah yaitu perlakuan T1 sebesar 3,89\%.
\end{abstract}

Kata Kunci: Tempe, Kacang Tanah, Kedelai

\begin{abstract}
Tempe is traditional Indonesian food that has been known for a long time. Research on the quality of tempe with variations of peanut and soybean aims to see the variation of tempe making using peanut and soybean. Quality testing in this study through organoleptic test and chemical analysis such as water content, ash content, and fat content.

The result of organoleptic test on flavour showed that panelist preferential level to T3 treatment was higher than $T 1$ and T2. The results of organoleptic test on aroma showed that T2 treatment was higher than T1 and T3. The result of organoleptic test on texture showed that $T 1$ was higher than $T 2$ and T3. The average water content of $T 1, T 2$, and $T 3$ respectively were $55,17 \%, 56,47 \%$, and 50,45\%. The average ash content of T1, T2, and T3 respectively were 0,59\%, 0,90\%, and 0,67\%. The highest fat content was T3 treatment $(4,93 \%)$ while the lowest fat content was $T 1$ treatment (3,89\%).
\end{abstract}

Keywords: Tempe, Peanut, Soybean

\section{Pendahuluan}

Konsumsi kedelai di Indonesia 50\% dalam bentuk tempe, $40 \%$ tahu dan $10 \%$ dalam bentuk produk lain (seperti tauco, kecap dan lain-lain). Konsumsi tempe rata-rata per orang per tahun di Indonesia saat ini sekitar 6,45 kg (Astawan, 2004). Tempe banyak diminati karena murah dan berprotein tinggi.

Pembuatan tempe dari kedelai meningkatkan penerimaan konsumen dari segi rasa dan meningkatkan nilai nutrisinya (Kasmidjo, 1990). Fermentasi pada tempe meningkatkan daya cerna karena proses hidrolisis dari protein, lemak, dan kandungan polisakarida kedelai.

Kacang tanah dan kedelai merupakan hasil pertanian yang banyak mengandung protein.
Penelitian ini berupaya untuk melihat potensi dari kacang tanah sebagai variasi dalam pembuatan tempe.

\section{Metode Penelitian}

Kedelai dan kacang tanah disortir kemudian ditimbang dan dicuci sampai bersih dalam loyang yang berisi air. Kedelai dan kacang tanah direbus selama \pm 30 menit dalam panci setelah air mendidih, menggunakan air, sampai setengah matang. Dilakukan pengupasan kulit kedelai dan kacang tanah dengan meremas-remasnya dalam air. Kedelai dan kacang tanah direndam selama \pm 24 jam dalam baskom plastik dengan menggunakan air $\pm 100 \mathrm{ml}$. Kedelai dan kacang tanah dicuci dan direbus sampai matang. Setelah matang diletakan di atas tempan dengan meratakan dan membiarkan hingga dingin sampai kedelai dan kacang tanah kering dan air 
yang menetes habis. Dicampurkan kacang tanah dan kedelai dangan perbandingan

T1 = kacang tanah \& kedelai $1: 1$

T2 = kacang tanah \& kedelai 1:2

T3 = kacang tanah \& kedelai 2:1

Kedelai dan kacang tanah dicampur dengan ragi sebanyak 1gram. Kedelai dan kacang tanah yang telah dicampur ragi dibungkus dengan daun pisang. Dilakukan pemyimpanan selama 2 hari pada suhu kamar. Diamati mutu kacang tanah dan kedelai pada pembungkus daun pisang.

Parameter yang diamati yaitu uji organoleptik yang meliputi rasa, aroma, warna, dan tekstur sedangkan analisis kimia berupa kadar air, kadar abu, dan kadar protein. Uji organoleptik ini dilakukan dengan mengunakan metode hedonik pada 30 orang panelis. Parameter yang akan diuji yaitu rasa, aroma, dan tekstur.

Pengujian kadar air menggunakan metode gravimetri. Cawan kosong dikeringkan dalam oven selama 15 menit dan didinginkan dalam desikator, ditimbang segera. Kemudian ditimbang kurang lebih 5 gram sampel yang sudah dihomogenkan dalam cawan. Cawan beserta isi ditempatkan di dalam oven pada suhu $100-102^{\circ} \mathrm{C}$ selama 6 jam. rumus berikut:

Kadar air dalam bahan dihitung dengan

Kadar air $==\frac{b-(c-a)}{b} \times 100 \%$

Keterangan:

a=berat cawan kering yang sudah konstan

$\mathrm{b}=$ berat sampel awal

$\mathrm{c}=$ barat cawan dan sampei kering yang sudah konstan

Pengujian kadar abu dilakukan dengan menimbang sebanyak 5 gram sampel, kemudian dimasukan ke dalam tanur dan di panaskan kemudian suhu dinaikan menjadi $420-550^{\circ} \mathrm{C}$ dengan waktu sesuai karakteristik bahan (umumnya 5-7 jam). Jika diperkirakan semua karbon belum teroksidasi, cawang diambil dari dalam tanur, lalu didinginkan di dalam desikator dapat ditambahkan 1-2 $\mathrm{ml} \mathrm{HNO}_{3}$ pekat. Sampel diuapkan sampai kering dan dimasukan kembali ke dalam tanur sampai pengabuan diangap selesai. Selanjutnya tanur diamati dan dapat dibuka setelah suhunya mencapai $250^{\circ} \mathrm{C}$ atau kurang. Cawan diambil dari dalam tanur kemudian ditimbang.

Kadar abu dalam sampel dihitung dengan rumus berikut:

Kadar Abu $=\frac{W 2-W 0}{W 1-W 0} \times 100 \%$

Keterangan :

W2=berat cawan+sampel setelah pengabuan

$\mathrm{W} 1=$ berat sampel awal

$\mathrm{W} 0=$ berat cawang kosong
Pengujian kadar lemak dilakukan dengan menyiapkan sebanyak 3 gram per sampel dibungkus dengan kertas saring, kemudian ditutup dengan kapas wool yang bebas lemak. Kertas saring yang berisi sampel tersebut dimasukan dalam alat ekstraksi soxhlet, kemudian dipasang alat kondensor di atasnya dan labu lemak di bawahnya. Pelarut yang ada di dalam labu lemak didestilasi dan ditampung. Dilakukan refluks minimum 5 jam sampai pelarut yang turun kembali ke labu lemak berwarna jernih. Pelarut yang ada di dalam labu lemak didestilasi dan ditampung. Labu lemak yang berisi hasil ekstraksi dipanaskan dalam oven pada suhu $105^{\circ} \mathrm{C}$, untuk menguapkan sisa pelarut yang mungkin masih tertinggal. Didinginkan dalam desikator dan dilakukan penimbangan hingga diperoleh bobot tetap.

Kadar lemak dalam sampel dapat dihitung:

Kadar lemak $=\frac{W c-W a}{W b} \times 100 \%$

Keterangan:

$\mathrm{W}_{\mathrm{c}}=$ Berat labu + lemak setelah ekstraksi $(\mathrm{g})$

$\mathrm{Wa}=$ Berat labu awal $(\mathrm{g})$

$\mathrm{W}_{\mathrm{b}}=$ Berat sampel $(\mathrm{g})$

\section{Hasil Dan Pembahasan}

\subsection{Rasa}

Nilai sensori tingkat kesukaan rasa dari variasi tempe kacang tanah dan kedelai dapat dilihat pada Gambar 1.

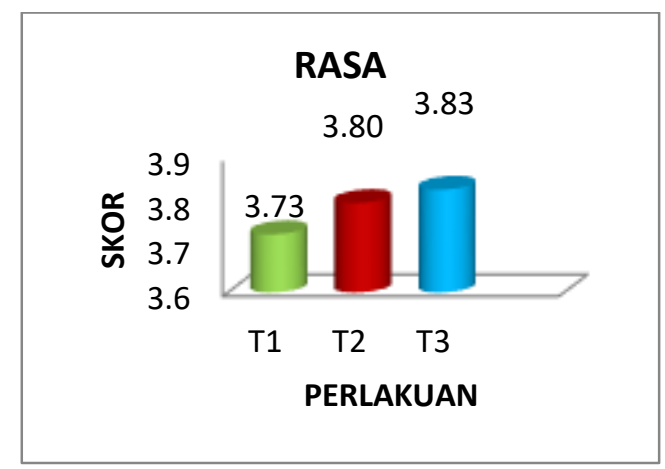

Gambar 1. Hasil uji organoleptik terhadap rasa tempe variasi kacang tanah dan kedelai

Berdasarkan hasil uji organoleptik terhadap rasa variasi tempe kacang tanah dan kedelai bahwa tingkat penerimaan panelis terhadap parameter rasa variasi tempe kacang tanah dan kedelai lebih disukai pada perlakuan T3 dibandingakan dengan perlakuan T1 dan T2. Tingkat kesukan panelis terhadap perlakuan T3 sebesar 3,83 sementara pada perlakuan T1 sebesar 3,73 dan T2 sebesar 3,80.

Hasil uji organoleptik terhadap rasa variasi tempe kacang tanah dan kedelai menujukan bahwa perlakuan T3 secara rata-rata berbeda dengan perlakuan T1 dan T2. Peningkatan rasa pada T3 disebabkan oleh kandungan lemak kacang tanah yang lebih tinggi dibanding kedelai. 


\subsection{Aroma}

Nilai sensori tingkat kesukaan Aroma dari variasi tempe kacang tanah dan kedelai dapat dilihat pada Gambar 2.

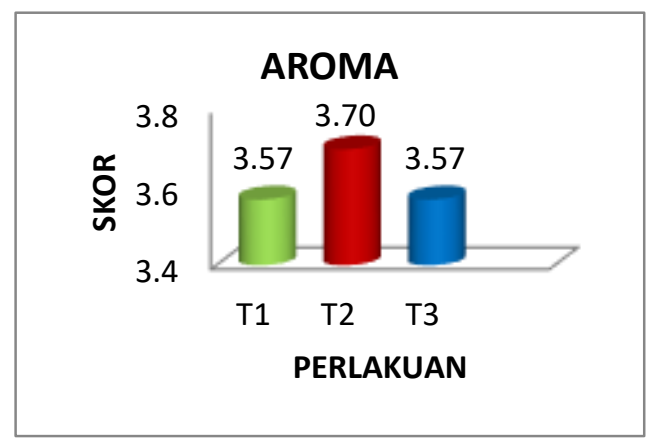

Gambar 2. Hasil uji organoleptik terhadap aroma tempe variasi kacang tanah dan kedelai

Hasil uji organoleptik terhadap aroma dari variasi tempe kacang tanah dan kedelai menujukan bahwa tingkat penerimaan panelis terhadap parameter aroma dari variasi tempe kacang tanah dan kedelai pada perlakuan T2 lebih tinggi dibandingkan dengan perlakuan T1 dan T3. Tingkat kesukan panelis terhadap perlakuan T2 sebesar 3,70 sementara pada perlakuan T1 3,57 dan T3 sebesar 3,57 .

Dari ketiga perlakuan ini T2 lebih disukai panelis, karena pada perlakuan tersebut kacang kedelai mengeluarkan aroma yang khas dari kacang tanah. Menurut Soekarto (1985), menyatakan bahwa komponen penyusun aroma terdiri dari senyawa volatile yang mudah menguap pada suhu tinggi. Hal ini dikarenakan proses pemasakan/perebusan kedelai membuat aroma yang spesifik.

\subsection{Tekstur}

Tekstur merupakan bagian penting dari mutu makanan, kadang-kadang lebih penting dari pada bau, rasa, dan warna. Nilai sensori tingkat kesukaan tekstur dari variasi tempe kacang tanah dan kedelai dapat dilihat pada Gambar 3

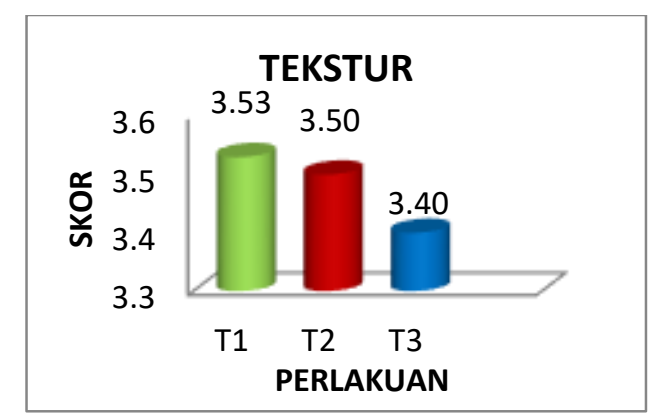

Gambar 3. Hasil uji organoleptik terhadap tekstur tempe variasi kacang tanah dan kedelai
Dari Gambar di atas, dapat dilihat bahwa tingkat kesukaan dari tekstur variasi tempe kacang tanah dan kedelai berkisar diantara 3,40 - 3,53 yaitu tingkat biasa/netral. Berdasarkan hasil uji organoleptik, panelis lebih menyukai tekstur formulasi T1. Hal ini dipengaruhi oleh formulasi kacang tanah dan kedelai memiliki ukuran/berat yang sama, dan menghasilkan tekstur yang disukai oleh panelis. Semakin banyak kacang tanah yang ditambahkan maka akan menurunkan tekstur tempe, sebaiknya lebih sedikit kacang tanah maka akan meningkatkan tekstur tempe, karena kosentrasi kacang tanah tidak melebihi berat kedelai, sehingga formulasi T1 lebih banyak disukai oleh panelis karena kedelai yang membuat tekstur tempe yang kompak. Menurut Winarno (1993), tekstur dipengaruhi oleh bahan baku yang digunakan mulai dari kadar pati, kadar lemak, kadar protein dan kadar air pada bahan tersebut.

\subsection{Kadar Air}

Hasil analisis rata-rata kadar air tempe kacang tanah dan kedelai dari tiga perlakuan, dengan tiga kali ulangan analisis dapat dilihat pada Gambar 4.



Berdasarkan Gambar di atas nilai rata - rata tempe kacang tanah dan kedelai berkisar antara $56,47 \%$ - 55,17\%. Dari analisis sidik ragam menyatakan bahwa $\mathrm{F}$ hitung $(2,00)$, lebih kecil $\mathrm{F}_{\text {tabel }}$ $(0,05)$ yaitu 5,14 . Sehingga tidak dilakukan uji lanjut BNT. Berdasarkan hasi analisis kadar air perlakuan yang diberikan tidak berpengaruh nyata terhadap kadar air pada kacang tanah.

Dari hasil penelitian tempe variasi kacang tanah dan kedelai telah dilakukan, nilai rata-rata kadar air yaitu T2 memiliki nilai kadar air 56,47 \%, T1 memiliki nilai kadar air 55,17 dan T3 memiliki nilai 50,45. karena semakin banyak penambahan kacang kedelai maka semakin tinggi kadar air pada tempe yang dihasilkan. Karna kacang kedelai itu sendiri memiliki kadar air yang cukup tinggi. Menurut Steinkraus (2008), bahwa perendaman akan memberikan kesempatan kepada kedelai untuk menyerap air (hidrasi) sehingga beratnya menjadi dua kali lipat dan dengan penyerapan tersebut, 
kedelai menyerap air lebih banyak ketika direbus, sehingga volumenya menjadi dua kali lipat.

\subsection{Kadar Abu}

Hasil analisis rata-rata kadar abu tempe kacang tanah dan kedelai dapat dilihat pada Gambar 5.

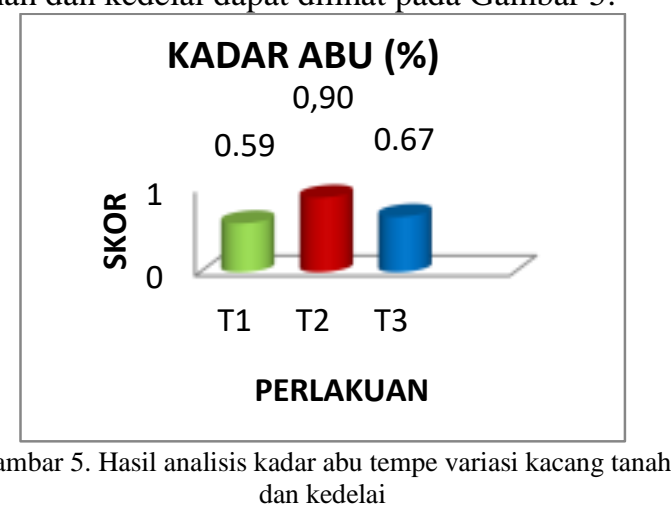

Berdasarkan analisis sidik ragam kadar abu bahwa $F_{\text {hitung }}(0,743)$ lebih kecil $F$ tabel $(0,05)$ yaitu 5,14 dan $F_{\text {tabel }}(0,01)$ yaitu 10,92 . Hasil analisis sidik ragam ini menunjukan dalam masing-masing formulasi tempe kacang tanah dan kacang kedelai tidak berpengaruh nyata terhadap nilai kadar abu pada ketiga perlakuan tersebut, sehingga tidak dilakukan uji lanjut BNT.

Rata-rata kadar abu variasi kacang tanah dan kedelai dengan perlakuan T2 memiliki nilai kadar abu tertinggi yaitu $0,90 \%$ selanjutnya T3 memiliki nilai kadar abu sebesar $0.67 \%$ dan T1 memiliki nilai kadar abu sebesar 0,59\%. Tinggi nilai kadar abu pada perlakuan T2 di sebabkan adanya perlakuan kacang kedelai yang lebih banyak dibandingkan kacang tanah. Hal ini yang membuat nilai kadar abu menjadi tinggi, sesuai pendapat Winarno (2004), semakin tinggi kadar abu suatu produk maka semakin tinggi pula kandunggan mineral pada produk tersebut, dan semakin rendah kadar abu suatu produk maka semakin rendah pula kandunggan mineral kandungan mineral produk tersebut.

\subsection{Kadar Lemak}

3.7.

Hasil analisis rata-rata kadar lemak tempe kacang tanah dan kedelai dapat dilihat pada Gambar 6.

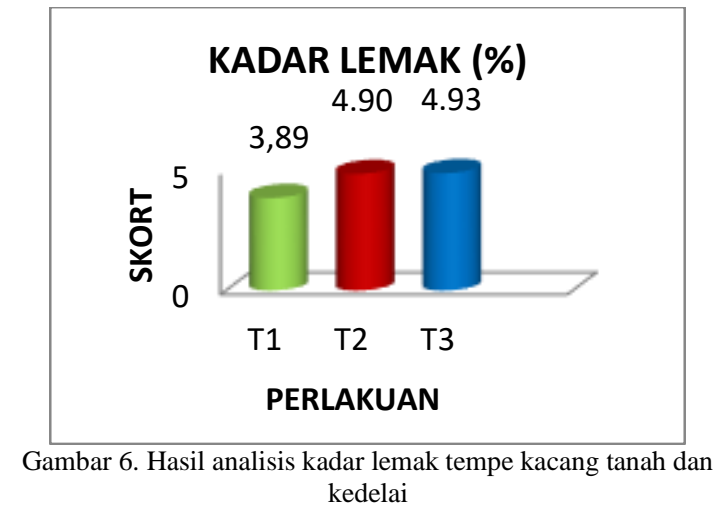

Berdasarkan analisis sidik ragam kada lemak bahwa $F_{\text {hitung }}(1,91)$ lebi kecil $F_{\text {tabel }}(0,05)$ yaitu 5,14. Hasil analisis sidik ragam ini menunjukan bahwa kombinasi antara kacang tanah dan kedelai tidak berpengaruh nyata terhadap kadar lemak. Sehingga tidak dilakukan uji lanjut BNT. Berdasarkan kadar lemak kacang tanah dan kedelai, kadar lemak yang tertinggi pada perlakuan T3 yaitu 4,93 sedangkan rata-rata kadar lemak yang terendah yaitu perlakuan T1 sebesar 3,89. Perbedaan kadar lemak dari tiga perlakuan tersebut, bahwa T3 banyak memiliki kacang tanah sehingga megandung banyaknya lemak dan memperoleh nilai yang tertinggi dibandingkan T1 dan T2.

\section{Kesimpulan}

Berdasarkan hasil pembahasan pada penelitian yang telah dilakukan pada variasi mutu tempe kacang tanah dan kedelai maka dapat disimpulkan bahwa variasi substitusi kacang tanah pada tempe kedelai tidak menunjukkan beda nyata. Kandungan lemak mempengaruhi penerimaan rasa panelis terlihat dari peningkatan rasa tempe variasi kedelai dan kacang tanah.

\section{DAFTAR PUSTAKA}

Astawan, M. 2004. Tetap Sehat dengan Produk Makanan Olahan. Tiga Serangkai, Solo.

Kasmidjo, RB. 1990. Tempe : Mikrobiologi dan Biokimia Pengolahan serta pemanfaatannya. Universitas Gadjah Mada, Yogyakarta.

Soekarto, ST. 1985. Penilaian Organoleptik untuk Industri Pangan dan Hasil Pertanian. Bhratara Karya Aksara, Jakarta.

Steinkraus, K. 2008. Handbook of Indigenous Fermented Foods. Taylor \& Francis Group, Inggris.

Winarno, FG. 1993. Pangan: Gizi, Teknologi dan Konsumen. PT Gramedia Pustaka Utama, Jakarta.

Winarno, FG. 1984. Kimia Pangan dan Gizi. Gramedia Pustaka Utama, Jakarta. 